Journal of Agricultural Sciences
(Tarim Bilimleri Dergisi)

\title{
Efficacy of Various Entomopathogenic Fungi Strains as Biocontrol Agents for Control of Callosobruchus maculatus (Fabricius) (Coleoptera: Bruchidae)
}

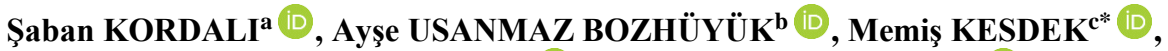 \\ Hacer Handan ALTINOK ${ }^{d} \mathbb{D}$, Mahmut Alper ALTINOK ${ }^{d} \mathbb{D}$ \\ ${ }^{a}$ Department of Plant Protection, Faculty of Fethiye Agriculture, Muğla Sttkı Koçman University, Fethiye, Muğla, TURKEY

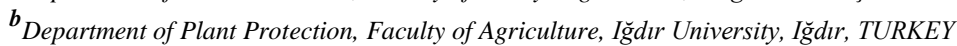 \\ ${ }^{c}$ Department of Environment Protection Technologies, Fethiye Ali Sitkı Mefharet Koçman Vocational High School, Muğla Sitkı Koçman University, Fethiye, Muğla, \\ TURKEY

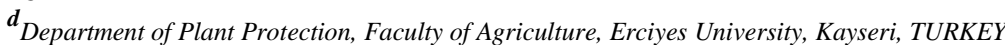

\section{ARTICLE INFO}

Research Article

Corresponding Author: Memiş KESDEK; E-mail: memiskesdek@mu.edu.tr

Received: 11 March 2020 / Revised: 21 May 2020 / Accepted: 08 June 2020 / Online: 04 December 2021

\section{ABSTRACT}

Cowpea seed beetle, Callosobruchus maculatus (F.) (Coleoptera: Bruchidae), is considered an important bruchid pest in cowpea seed storages. The used pesticides against this pest have caused the occurrence of resistant populations and direct toxicity to the users. The objective of this study was to evaluate the mortality effects of six entomopathogenic fungi isolates obtained from ARSEF (USA) collection [Paecilomyces farinosus (2538), Isaria fumosorosea (4501), Isaria farinosa (3580), Beauveria bassiana (4984), Lecanicillium muscarium (972) and Lecanicillium muscarium (5128)] against $C$. maculatus adults under laboratory conditions $\left(26 \pm 2{ }^{\circ} \mathrm{C}, 70 \pm 5 \% \mathrm{RH}\right.$ and 16h light: $8 \mathrm{~h}$ dark). The isolates were cultivated in Potato Dextrose Agar (PDA, Oxoid, CM0139) medium at $26 \pm 2{ }^{\circ} \mathrm{C}$ in dark conditions for two weeks before using them as control agents. Spore suspensions of the isolates were prepared at two different concentrations $\left(1 \times 10^{5}\right.$ and $\left.1 \times 10^{7}\right)$ and mixed with Tween $20(0.04 \%)$. Each concentration was replicated three times and the mortality rates were observed on the $2^{\text {nd }}, 4^{\text {th }}, 6^{\text {th }}, 8^{\text {th }}$ and $10^{\text {th }}$ day of incubations. As a commercial control, a Mycotal extraction of $L$. muscarium and as a negative control, Tween 20+sterile water was used. Six entomopathogenic fungal isolates at both conidial concentrations yielded high mortalities (from $62.6 \%$ to $100 \%$ ) of $C$. maculatus adults. These results illustrated that tested fungi strains led to significant mortalities on $C$. maculatus adults in all the treatments as compared to the controls. Consequently, these fungi strains were regarded as an encouraging alternative method to control the population of $C$. maculatus adults in the stored cowpea grains.

Keywords: Entomopathogenic fungus, Biological control, Cowpea seed beetle, Bruchid

(C) Ankara University, Faculty of Agriculture

\section{Introduction}

Legume plants are very important source of protein for human feeding in undeveloped countries. Among them, cowpea (Vigna unguiculata (L.) Walp.: Fabaceae) is grown for its green beans and seeds by farmers especially in tropical and subtropical regions of the world. It is also cultivated all over the world for animal feed (Ofuya \& Akhidue 2005). Due to their prosperous source of nutritious elements, the fresh and green crusts of cowpea are consumed as vegetable. In addition, the leaf, branch and stem parts of the plant are used as fresh animal food for livestocks (Remya 2007).

Cowpea seed beetle (Callosobruchus maculatus (F.) (Coleoptera: Bruchidae)) is one of the most destructive pests on cowpea and other legumes growing in tropical and sub-tropical countries, both in fresh green crusts in fields and in stored seeds (Singh \& Van Emden 1979). The adults are not harmful. But, the larvae of this pest feed on cowpea (V. unguiculata (L.)), chickpea (Cicer arietinum L.), lentil (Lens culinaris Medik.), soybean (Glycine max Mer.) and haricot beans (Phaseolus vulgaris L.) (Mahfuz \& Khalequzzaman 2007). The female adults of $C$. maculatus lay their eggs in the fresh cowpeas before the reaping in the field. The larvae from these eggs bore into the cowpea seeds, develop by feeding the embryo of the seeds and mature just about in a month in storage conditions (Fox \& Tatar 1994). Therefore, the larvae can lead to both quantitative (due to grain weight loss caused by larvae feeding) and qualitative (due to product alterations such as loss of nutritious and aesthetic values, resulting increased levels of losses in the grain mass) damages on cowpea grains (Moina et al. 1998). This pest requires great care due to the potentials of severe damages mentioned above.

In the past, many commercial and persistent insecticides such as Phosphine, Methyl bromide, Deltamethrin and Malathion were largely used to control this pest in stored cowpea. But, these chemicals pose risks such as food and environmental 
pollution, toxicities to non-target organisms, pest resistance, pesticide residues, direct toxicities to users and ozone depletion (Arthur 1996; Isman 2006; Khashaveh et al. 2011). Therefore, health authorities are reluctant to allow chemical insecticides due to their residues on stored grains. New alternative control strategies are required, because the commercial insecticides have quite toxic impacts on environment and human health. The growing research on biological protectant alternatives has revealed the positive role of microbial insecticides (Sheeba et al. 2001). One of the most promising and environment-friendly alternatives for pest control is entomopathogenic fungi. They are among the first entomopathogenic organisms used against harmful arthropods. Entomopathogenic fungi cause disease by infecting to insects or other arthropods and subsequently provoke rapid declines in large populations of their arthropod hosts. They have garnered the most interest to research for utilizing as microbial insecticides. For these reasons, their roles are crucial on biological control of hazardous insects because of environmentally safe and very low toxicity to mammalians (Cox \& Wilkin 1996). The use of entomopathogenic fungi for biological control of the pests is an attractive alternative to classical pesticides, because these beneficial fungi are very friendly control agents against a wide range of organisms, and have no detrimental effects on environment (Khetan 2001; Sevim et al. 2013). Therefore, entomopathogenic fungi could be a viable alternative method to control this pest. Up to now, there are many studies with the use of entomopathogenic fungi to control insect pests, but very little focused on using fungi as control agents against stored product pests (Ferroni 1977; Serale \& Doberski 1984; Moina et al. 1998; Sheeba et al. 2001; Gökçe \& Er 2005; Sevim et al. 2010; Shifa Vanmathi et al. 2011; Muştu et al. 2014; Reddy et al. 2014; Erler \& Ateş 2015; Komaki et al. 2017; Usanmaz Bozhüyük et al. 2018; Bjornson \& Elkabir 2019).

The main objective of the present study was to investigate the efficacies of various entomopathogenic fungi isolates [(Paecilomyces farinosus (2538), Isaria fumosorosea (4501), I. farinosa (3580), Beauveria bassiana (4984), Lecanicillium muscarium (972) and L. muscarium (5128))] for the control of the adults of important and destructive storage pest; $C$. maculatus, under laboratory conditions.

\section{Material and Methods}

\subsection{Storage pest insect}

Callosobruchus maculatus (F.) (Coleoptera: Bruchidae) adults were collected from private store houses in Muğla, Turkey and kept on cowpea (Vigna unguiculata (L.) seeds. After, a certain amount of cowpea seeds was purchased from a local market and maintained at a freezer in two days at $-15{ }^{\circ} \mathrm{C}$ in order to prevent any arthropod pests prior to in the bioassay. Then, $C$. maculatus adults were reared in $1 \mathrm{~L}$ jars containing cowpea seeds. The cultures were maintained in the dark conditions in a growth chamber set at $26 \pm 2{ }^{\circ} \mathrm{C}$ and $70 \pm 5 \% \mathrm{RH}$ without exposure to any insecticide for several generations. Newly emerged adults (three days-old, mixed males and females) were used for subsequent experiments. All experimental procedures were carried out under the same conditions as the cultures. Experiments were carried out in three replicates with 25 adults of this pest in each Petri dish. Sufficient amount (1 seed/1 insect) of cowpea seeds were placed in each Petri dish for the adult insects during entomopathogenic tests.

\section{2. Entomopathogenic fungi isolates and preparation}

The entomopathogenic fungi strains [(Paecilomyces farinosus (2538), Isaria fumosorosea (4501), I. farinosa (3580), Beauveria bassiana (4984), Lecanicillium muscarium (972) and L. muscarium (5128)] were obtained from an entomopathogenic fungi collection (ARSEF, USA). Another L. muscarium isolate, used as commercial control, was obtained from a commercial product (Mycotal, Koppert, NL). Fungal isolates were cultivated in the Potato Dextrose Agar (PDA, Oxoid, CM0139) medium at $26 \pm 2{ }^{\circ} \mathrm{C}$ in dark for two weeks and used as spray source on the storage pests. Harvested conidia from 14day-old cultures grown on PDA plates were thoroughly mixed with the carrier in screw capped bottles in $3 \mathrm{~mL}$ distilled sterile water. Spore solutions of entomopathogenic fungi isolates were prepared at $1 \times 10^{5}$ and $1 \times 10^{7}$ concentrations and mixed with Tween $20(0.04 \%)$. The suspension was sieved and $1 \mathrm{~mL}$ of prepared suspension was sprayed on each replicate of 25 beetles in each Petri dishes. The sprayed Petri dishes were then incubated in an incubator at $26 \pm 2{ }^{\circ} \mathrm{C}$ and the dead beetles were counted in each $48 \mathrm{~h}$. For evaluating the conidial viability, the spores of different isolates were saved in the suspension of distilled sterile water and Tween 20, checked by light microscopy (Olympus BH2) after 2, 4, 6, 8 and 10 days.

\section{3. Bioassays}

In order to test the toxicity of six entomopathogenic fungi, the applications were carried by adding $1 \times 10^{5}$ and $1 \times 10^{7}$ conidia to $1 \mathrm{~mL}$ in $9 \mathrm{~cm}$ diameter sterile Petri dishes with two layers of drying paper. Then, 25 newly emerged adults of $C$. maculatus were collected with an aspirator and placed in each Petri dish. Separately, sufficient amount of cowpea seeds (1 seed/1 insect) were added to each Petri dish. The prepared entomopathogenic fungal suspensions were sprayed on the adults and seeds contained in Petri dishes and incubated at $26 \pm 2{ }^{\circ} \mathrm{C}$. Each assay was repeated three times for each dose and exposure time combination. Mycotal extraction of L. lecanii was utilized as commercial control and distilled sterile water with Tween 20 as negative control in the study. After these treatments, the alive and dead C. maculatus adult individuals were counted in every $48 \mathrm{~h}$ for 10 days (Table 1 ). 
Table 1- Percent mortalities of Callosobruchus maculatus (Fab.) adults inoculated with two different conidial concentrations $\left(1 \times 10^{5}\right.$ and $\left.1 \times 10^{7}\right)$ of six entomopathogenic fungi isolates

\begin{tabular}{|c|c|c|c|c|c|c|}
\hline \multirow{4}{*}{$\begin{array}{c}\text { Treatment } \\
\text { Entomopathogenic } \\
\text { fungi }\end{array}$} & \multicolumn{6}{|c|}{ Callobruchus maculatus (Fabricius) } \\
\hline & \multirow{3}{*}{ Dose } & \multicolumn{5}{|c|}{$\operatorname{Mortality}(\%)^{a}$} \\
\hline & & \multicolumn{5}{|c|}{ Days After Treatment ${ }^{b}$} \\
\hline & & 2 & 4 & 6 & 8 & 10 \\
\hline Paecilomyces farinosus & $1 \times 10^{5}$ & $65.3 \pm 3.52 \mathrm{bc}$ & $73.3 \pm 4.80 \mathrm{bc}$ & $84.0 \pm 8.0 \mathrm{~b}$ & $94.6 \pm 2.66 \mathrm{~cd}$ & $97.3 \pm 1.33 \mathrm{bc}$ \\
\hline (2538) & $1 \times 10^{7}$ & $90.6 \pm 7.42 \mathrm{e}$ & $92.0 \pm 6.11 \mathrm{~cd}$ & $98.6 \pm 1.33 \mathrm{de}$ & $100 \pm 0.0 \mathrm{e}$ & $100 \pm 0.0 \mathrm{c}$ \\
\hline Isaria fumosorosea & $1 \times 10^{5}$ & $77.3 \pm 11.3 \mathrm{bcde}$ & $84.0 \pm 8.0 \mathrm{bcd}$ & $90.6 \pm 4.80 \mathrm{bcde}$ & $97.3 \pm 1.33 \mathrm{cde}$ & $98.6 \pm 1.33 b c$ \\
\hline$(4501)$ & $1 \times 10^{7}$ & $76.0 \pm 0.0 \mathrm{bcde}$ & $80.0 \pm 2.30 \mathrm{bcd}$ & $86.6 \pm 5.33 b c$ & $97.3 \pm 1.33 \mathrm{cde}$ & $100 \pm 0.0 \mathrm{c}$ \\
\hline Beauveria bassiana & $1 \times 10^{5}$ & $78.6 \pm 13.3 \mathrm{bcde}$ & $78.6 \pm 13.3 \mathrm{bcd}$ & $89.3 \pm 4.80 \mathrm{bcde}$ & $98.6 \pm 1.33 \mathrm{de}$ & $100 \pm 0.0 \mathrm{c}$ \\
\hline (4984) & $1 \times 10^{7}$ & $86.6 \pm 6.66 \mathrm{de}$ & $86.6 \pm 6.66 \mathrm{bcd}$ & $100 \pm 0.0 \mathrm{e}$ & $100 \pm 0.0 \mathrm{e}$ & $100 \pm 0.0 \mathrm{c}$ \\
\hline Lecanicillium muscarium & $1 \times 10^{5}$ & $62.6 \pm 4.80 \mathrm{~b}$ & $70.6 \pm 4.80 \mathrm{~b}$ & $90.6 \pm 4.80 \mathrm{bcde}$ & $98.6 \pm 1.33 \mathrm{de}$ & $98.6 \pm 1.33 b c$ \\
\hline (972) & $1 \times 10^{7}$ & $84.0 \pm 12.0 \mathrm{cde}$ & $92.0 \pm 4.0 \mathrm{~cd}$ & $97.3 \pm 2.66 \mathrm{cde}$ & $100 \pm 0.0 \mathrm{e}$ & $100 \pm 0.0 \mathrm{c}$ \\
\hline Isaria farinosa & $1 \times 10^{5}$ & $72.0 \pm 12.0 \mathrm{bcde}$ & $72.0 \pm 12.0 \mathrm{~b}$ & $85.3 \pm 8.11 b$ & $98.6 \pm 1.33 \mathrm{de}$ & $100 \pm 0.0 \mathrm{c}$ \\
\hline$(3580)$ & $1 \times 10^{7}$ & $78.6 \pm 2.30 \mathrm{de}$ & $88.0 \pm 9.33 \mathrm{bcd}$ & $97.3 \pm 1.33 \mathrm{cde}$ & $100 \pm 0.0 \mathrm{e}$ & $100 \pm 0.0 \mathrm{c}$ \\
\hline Lecanicillium muscarium & $1 \times 10^{5}$ & $69.3 \pm 7.05 \mathrm{bcd}$ & $74.6 \pm 9.33 b c$ & $88.0 \pm 6.11 \mathrm{bcd}$ & $93.3 \pm 3.52 c$ & $97.3 \pm 2.66 b c$ \\
\hline$(5128)$ & $1 \times 10^{7}$ & $89.3 \pm 5.33 \mathrm{e}$ & $96.0 \pm 2.30 \mathrm{~d}$ & $98.6 \pm 1.33 \mathrm{de}$ & $100 \pm 0.0 \mathrm{e}$ & $100 \pm 0.0 \mathrm{c}$ \\
\hline Commercial Control & $1 \times 10^{5}$ & $78.6 \pm 1.33 \mathrm{bcde}$ & $84.0 \pm 2.30 \mathrm{bcd}$ & $89.3 \pm 1.33 \mathrm{bcde}$ & $89.3 \pm 1.33 b$ & $96.0 \pm 2.30 b c$ \\
\hline (L. muscarium (Mycotal)) & $1 \times 10^{7}$ & $82.6 \pm 7.42 \mathrm{cde}$ & $82.6 \pm 7.42 \mathrm{bcd}$ & $88.0 \pm 2.30 \mathrm{bcd}$ & $89.3 \pm 1.33 b$ & $94.6 \pm 3.52 b$ \\
\hline $\begin{array}{c}\text { Negative Control } \\
\text { (Tween20+steril water) }\end{array}$ & - & $0.0 \pm 0.0 \mathrm{a}$ & $1.33 \pm 1.11 \mathrm{a}$ & $1.33 \pm 1.11 \mathrm{a}$ & $2.66 \pm 1.11 \mathrm{a}$ & $2.66 \pm 1.11 \mathrm{a}$ \\
\hline
\end{tabular}

${ }^{\mathrm{a}}$ : Numbers in each column are Mean \pm SE of three replicates, each set-up with 25 adults; ${ }^{\text {b}}:$ Exposure duration (day)

*: Values followed by different letters in the same column differ significantly at $\mathrm{P}<0.05$

\section{4. Statistical analysis}

Percent mortalities of $C$. maculatus adults were subjected to ANOVA with SPSS 17.0 software package and means were separated by Duncan's multiple range test at $\mathrm{P}<0.05$.

\section{Results}

Mortality rates of Callosobruchus maculatus (F.) (Coleoptera: Bruchidae) adults treated with six entomopathogenic fungi isolates are provided in Table 1. The results showed that all tested entomopathogenic fungi isolates had different mortality effects on $C$. maculatus adults as compared to control treatments. In all experiments, the mortality rates generally increased with increasing exposure durations. The strain used as commercial control (Lecanicillium muscarium, Mycotal) was failed to achieve $100 \%$ mortality and the greatest rate of mortality with this L. muscarium strain was $94.6 \%$. According to the results, the earliest $100 \%$ mortality on C. maculatus adults were obtained at 6 days after treatment (DAT) with Beauveria bassiana (4984) sprayed at $1 \times 10^{7}$ spore concentration, under $26 \pm 2{ }^{\circ} \mathrm{C}$ and $70 \pm 5 \% \mathrm{RH}$. On the other hand, mortality rates were considerable higher even in the first day counts (2 DAT), $1 \times 10^{7}$ concentration of Paecilomyces farinosus (2538) provided over $90 \%$ average mortality, where $B$. bassiana isolate (4501) killed $78.6 \%$ of the adults at lower $\left(1 \times 10^{5}\right)$ dosage, which was on par with the same dosage mortality results of commercial control (L. muscarium). In the second count day (4 DAT), one of the $L$. muscarium isolates (5128) were able to kill about $96 \%$ of the adults at $1 \times 10^{7}$ dosage while Isaria fumosorosea (4501) treatments at lower dose have the highest mortality (84.0\%) among the others. All of the isolates, except for I. fumosorosea, displayed over $95 \%$ mortality at $6^{\text {th }}$ day after treatments. The second greatest mortality at that day was achieved in $L$. muscarium (5128) treated Petri dishes, $98.6 \%$ of adults were recorded dead at high-dose treatments, which was closely followed by $I$. farinosa $(98.6 \%)$, again at $1 \times 10^{7}$ spore concentration. In the $8^{\text {th }}$ day after treatments, $100 \%$ of the adults were dead in Petri dishes treated with the higher dose of entomopathogenic isolates, again, with the exception of I. fumosorosea. And finally, at $10^{\text {th }}$ day, over $97 \%$ mortality was recorded in all fungi, tested. As seen in Table 1 , the first two days $\left(2^{\text {nd }}\right.$ and $\left.3^{\text {rd }}\right)$ and second two days ( $6^{\text {th }}$ and $8^{\text {th }}$ ) had different efficiency levels. It is also worth to mention that all isolates yielded significantly different results at lower and higher dosages, but I. fumosorosea treatment yielded similar outcomes throughout the experimental period, except for $4^{\text {th }}$ day.

\section{Discussion}

In this study, six entomopathogenic fungi isolates [(Paecilomyces farinosus (2538), Isaria fumosorosea (4501), I. farinosa (3580), Beauveria bassiana (4984), Lecanicillium muscarium (972) and L. muscarium (5128)] were found as pathogenic on C. maculatus adults. Mortality rates of all isolates on $C$. maculatus adults, at both doses $\left(1 \times 10^{5}\right.$ and $\left.1 \times 10^{7}\right)$, increased gradually with longer exposure durations. Mortality of $C$. maculatus adults varied between 97.3 and $100 \%$. Specifically, the adult mortalities were $97.3 \%$ with L. muscarium (5128) and P. farinosus (2538) at $1 \times 10^{5}$ dose on $10^{\text {th }}$ day of treatment and $100 \%$ with all tested entomopathogenic fungi isolates at $1 \times 10^{7}$ dose (Table 1). 
Many studies were carried out by different researchers about the mortality effects of various entomopathogenic fungi against $C$. maculatus. Currently, B. bassiana has been identified as one of the most successful entomopathogenic fungi. The use of $B$. bassiana to control $C$. maculatus was studied by various researchers worldwide. Cherry et al. (2005) reported that the evolution of cumulative mortality among $C$. maculatus adults following immersion in aqueous conidial suspensions of $B$. bassiana 0362 yielded greater efficacy for $B$. bassiana 0362 . The same authors pointed out that this was the most noticeable at $1 \times 10^{8}$ conidia $\mathrm{mL}^{-1}$ where $100 \%$ mortality was achieved with $B$. bassiana 0362 after 6 days of treatment. Draganova et al. (2007) found that the isolates 417, 412, 414 and 426 of B. bassiana caused mycoses on $C$. maculatus adults, and the highest lethal effect to $C$. maculatus adults was expressed as $100 \%$ mortality on the $6^{\text {th }}, 7^{\text {th }}$ and $8^{\text {th }}$ day, respectively. Shifa Vanmathi et al. (2011) recorded the mortality rates at $1 \times 10^{5}(40 \%, 80 \%, 85.70 \%, 91.52 \%, 97.90 \%)$ and $1 \times 10^{7}$ doses $(13.33 \%, 33.33 \%$, $71.42 \%, 71.42 \%$ and $97.78 \%$ ) after $24,48,72,92$ and $120 \mathrm{~h}$ on C. maculatus adults, respectively. Kılıç et al. (2019) determined that nine different isolates of $B$. bassiana led to different mortality rates at $1 \times 10^{7}$ dose and after $12 \mathrm{~h}$ of treatment on Helicoverpa armigera (Hübner) (51.9-68.1\%), Spodoptera littoralis (Hübner) (45.5-54.4\%), Tenebrio molitor (L.) (66.7$81.5 \%)$ and Blattella germanica (L.) (3.33-6.70\%). In present study, B. bassiana (4984) isolates caused the mortality rates at $1 \times 10^{5}(86.60 \%, 86.60 \%, 100 \%, 100 \%, 100 \%)$ and $1 \times 10^{7}$ doses $(78.60 \%, 78.60 \%, 89.30 \%, 98.60 \%, 100 \%)$ after $2,4,6,8$ and 10 days of the treatments on $C$. maculatus adults, respectively (Table 1). I. fumosorosea has been known as a common entomopathogenic fungus all over the world for more than 30 years (Zimmermann 2008). Sevim et al. (2013) determined that I. fumosorosea KTU-42 caused different mortality rates on C. ciliata adults (63\%) and nymphs (50\%). In the present study, we found that $I$. fumosorosea (4501) isolate caused different mortality rates in the $1 \times 10^{5}(76 \%, 80 \%, 86.6 \%, 97.3 \%, 100 \%)$ and $1 \times 10^{7}(77.3 \%, 84 \%, 90.6 \%, 97.3 \%, 98.6 \%)$ doses after $2,4,6,8$ and 10 days of the treatments on C. maculatus adults, respectively (Table 1). I. farinosa is one of the most the commercially produced entomopathogenic fungi, which have an estimated 700 species of entomopathogenic fungi in approximately 90 genera. Yang et al. (2009) stated that I. farinosa had mortality effect on the larvae, pupae and adults of Pissodes punctatus (Coleoptera: Curculionidae) up to $88 \%$. In another study, Muştu et al. (2011) recorded that on the $9^{\text {th }}$ and $12^{\text {nd }}$ days of the incubation, I. farinosa caused different mortality rates $(22.5$ and $45 \%)$ at $1 \times 10^{6}$ and $1 \times 10^{8}$ conidial concentrations $\left(\mathrm{mL}^{-1}\right)(52.5$ and $70 \%)$ on A. rostrata adults. Correlatively, Demirci et al. (2011) found that I. farinosa had different mortality rates at $1 \times 10^{8}, 1 \times 10^{7}, 1 \times 10^{6}, 1 \times 10^{5}$ doses and $95 \%$ RH on the adults of Planococcus citri (Risso) $(84.53 \%$, 32.29\%, 19.24\%, 20.54\%), respectively. Muştu et al. (2014) determined that I. farinosa isolate had significant mortality on the sun pest adults (Eurygaster austriaca (Schrk.)). They found that I. farinosa caused different mortality rates $(0.00 \%, 5.00 \%, 10.00 \%$ and $33.75 \%, 63.75 \%, 86.25 \%)$ at $1 \times 10^{6}$ and $1 \times 10^{8}$ conidia concentration doses $\mathrm{mL}^{-1}$ after 6, 9 and 12 days of treatments on $E$. austriaca adults, respectively. In present study, I. farinosa (3580) isolate caused different mortality rates $(72 \%, 72 \%, 85.3 \%, 98.6 \%, 100 \%$; and $78.6 \%, 88 \%, 97.3 \%, 100 \%, 100 \%$, respectively) at $1 \times 10^{5}$ and $1 \times 10^{7}$ doses on the $2^{\text {nd }}, 4^{\text {th }}, 6^{\text {th }}$ and $10^{\text {th }}$ days of the treatment on $C$. maculatus adults. These percentages were significantly higher than the control $(\mathrm{P}<0.05)$ (Table 1). P. farinosus has been known as an effective entomopathogenic fungus for more than 30 years. Today, because it is one of the most important biocontrol agents, its various strains are successfully used for biocontrol of different pestiferous insects, such as whiteflies (Zimmermann 2008). Vidal et al. (1997) demonstrated that 29 isolates of $P$. farinosus had highly significant mortality (from 68 to 94\%) on the silverleaf whitefly, Bemicia argentifolii Bellows \& Perring. Simova \& Draganova (2003) found that P. farinosus had a mortality effect on two spotted spidermite, Tetranychus urticae K.. In another study, it was stated that P. farinosus isolates (290 and 290re) showed lethal effect on Ips sexdentatus Boer. and I. acuminatus Gyll. adults (45.00 and $66.67 \%$, respectively) at $1 \times 10^{8}$ conidia/mL (Draganova et al. 2007). In this study, it was found that $P$. farinosus isolate (2538) caused different mortality rates on $C$. maculatus adults in the $1 \times 10^{5}$ and $1 \times 10^{7}$ doses after $2,4,6$ and 10 days of the treatments, as $90.6 \%, 92.0 \%, 98.6 \%, 100 \%$, $100 \%$; and $65.3 \%, 73.3 \%, 84.0 \%, 94.6 \%$ and $97.3 \%$, respectively (Table 1). L. muscarium is also among the important entomopathogenic fungi. It is known as one of the important natural enemies of Scolypopa australis (Walker) in kiwi orchards (Marshall et al. 2003). This fungus is a commercially produced entomopathogenic fungi and has been commercialized worldwide as the biopesticides Mycotal (a commercial formulation of L. muscarium produced) against whiteflies and thrips; and Verticillin against whiteflies, aphids and mites (Faria \& Wraight 2007). In a previous study, it was stated that $L$. muscarium isolates had mortality effects on the adults and nymphs of Bactericera cockerelli (Sulc) (up to $100 \%$ for adults and $70 \%$ for nymphs) at the $1 \times 10^{7}$ dose after seven days of the treatments (Mauchline \& Stannard 2013). In present study, $L$. muscarium isolate (972) caused greater mortality effect $(84.0 \%, 92.0 \%, 97.3 \%, 100 \%, 100 \%)$ at $1 \times 10^{7}$ dose than at $1 \times 10^{5}$ dose $(62.6 \%, 70.6 \%, 90.6 \%, 98.6 \%, 98.6 \%)$ within all exposure times of the treatments on C. maculatus adults. However, $L$. muscarium isolate $(5128)$ caused $89.3 \%, 96.0 \%, 98.6 \%, 100 \%$ and $100 \%$ mortality rates at $1 \times 10^{7}$ dose and after $2,4,6,8$ and 10 days on $C$. maculatus adults in this study, respectively. But, the same fungus isolate had lower mortality effect $(69.3 \%$, $74.6 \%, 88.0 \%, 93.3 \%$ and $97.3 \%)$ at $1 \times 10^{5}$ dose and within the same exposure times. These percentages were significantly higher than the control $(\mathrm{P}<0.05)$ (Table 1). Komaki et al. (2017) tested six entomopathogenic fungi isolates $((P$. farinosus (2538), I. fumosorosea (4501), I. farinosa (3580), B. bassiana (4984), L. muscarium (972) and L. muscarium (5128)) against Tribolium confusum du Val., 1863 adults under laboratory conditions. In their study, these entomopathogenic fungi isolates led to the mortalities between 37.3 (for I. farinosa (3580) at $1 \times 10^{5}$ dose) and $100 \%$ (for P. farinosus (2538) and B. bassiana (4984) at $1 \times 10^{7} \mathrm{dose}$ ) on $T$. confusum adults after 10 days of treatment. In present study, the mortality rates were recorded as between 62.6 (for L. muscarium (972) at $1 \times 10^{5}$ dose) and $100 \%$ (for all fungi isolates at different doses) on C. maculatus adults after 10 days of treatment. According to these results, six fungi isolates showed greater effect on C. maculatus adults than T. confusum adults (Table 1). 


\section{Conclusions}

In the present study, six entomopathogenic fungi isolates [(P. farinosus (2538), I. fumosorosea (4501), I. farinosa (3580), B. bassiana (4984) and L. muscarium (2 isolates)] were tested against $C$. maculatus adults under laboratory conditions. Among the tested fungi isolates, L. muscarium (972) caused the greatest mortality rates (between 84 and $100 \%$ ) on C. maculatus adults at $26 \pm 2{ }^{\circ} \mathrm{C}, 70 \pm 5 \% \mathrm{RH}$ and with $1 \times 10^{7}$ conidial concentrations $\left(\mathrm{mL}^{-1}\right)$ on the $2^{\text {nd }}, 4^{\text {th }}, 6^{\text {th }}, 8^{\text {th }}$ and $10^{\text {th }}$ days. The lowest mortality was recorded at $1 \times 10^{5}$ conidial concentration of L. muscarium (972) isolate as $62.60 \%$ on the $2^{\text {nd }}$ day of the treatment. Present findings showed that the fungal isolates used in this study could be used as possible biocontrol agents against $C$. maculatus adults. Further studies should be carried out to evaluate the effectiveness of these isolates in the field. It was concluded that use of biological control agent of L. muscarium (972) isolate as a part of integrated pest management strategy may reduce the future dependence on chemical control.

\section{Acknowledgments}

Authors thank Amanmohammad Komaki, translator and native English speaker, for his worthy contributions in revising the English of this article; Duygu Şimşek for her helps in different stages of the study, and Yahya Nas for his technical contributions.

\section{References}

Arthur F H (1996). Grain protectants: current status and prospects for the future. Journal of Stored Product Research 32: 293-302

Bjornson S \& Elkabir E (2019). Effects of the microsporidian pathogen, Nosema adaliae (Nosematidae) on the seven-spotted lady beetle, Coccinella septempunctata L. (Coleoptera: Coccinellidae). Journal of Invertebrate Pathology 168: 1-5 https://doi.org/10.1016/j.jip.2019.107253

Cherry A J, Abalob P \& Hella K (2005). A laboratory assessment of the potential of different strains of the entomopathogenic fungi Beauveria bassiana (Balsamo) Vuillemin and Metarhizium anisopliae (Metsch.) to control Callosobruchus maculatus (F.) (Coleoptera: Bruchidae) in stored cowpea. Journal of Stored Product Research 41: 295-309

Cox P D \& Wilkin D R (1996). The potential use of biological control of pests in stored grain. Research Review, 36. Home-Grown Cereals Authority, London, England pp. 1-53

Demirci F, Mustu M, Kaydan M B \& Ulgentürk S (2011). Laboratory evaluation of the effectiveness of the entomopathogen; Isaria farinosa, on citrus mealybug, Planococcus citri. Journal of Pest Science 84: 337-342 https://doi.org/10.1007/s10340-011-0350-9

Draganova S, Staneva E \& Georgieva D (2007). Bioassays with isolates of the entomopathogenic fungus Beauveria bassiana (Bals.) Vuill. against adults of Callosobruchus maculatus F. (Coleoptera: Bruchidae). Acta Entomologica Bulgaria 13(3): 104-111 https://doi.org/10.9734/jaeri/2021/v22i230185

Draganova S, Takov D \& Doychev D (2007). Bioassays with isolates of Beauveria bassiana (Bals.) Vuill. and Paecilomyces farinosus (Holm.) Brown \& Smith against Ips sexdentatus Boerner and Ips acuminatus Gyll. (Coleoptera: Scolytidae). Plant Science, 44(1): 24-28

Erler F \& Ateş Ö (2015). Potential of two entomopathogenic fungi, Beauveria bassiana and Metarhizium anisopliae (Coleoptera: Scarabaeidae), as biological control agents against the June beetle. Journal of Insect Science 15(1): 1-6 https://doi.org/10.1093/jisesa/iev029

Faria M R D \& Wraight S P (2007). Mycoinsecticides and Mycoacaricides: A comprehensive list with worldwide coverage and international classification of formulation types. Biological Control 43: 237-256. https://doi.org/10.1016/j.biocontrol.2007.08.001

Ferroni P (1977). Influence of relative humidity on the development of fungal infection caused by Beauveria bassiana in imagines of Acanthoscelides obtectus. Entomophaga 22: 393-396 https://doi.org/10.1007/bf02373264

Fox W C \& Tatar M (1994). Oviposition substrate affects adult mortality, independent of reproduction, in the seed beetle Callosobruchus maculatus. Ecological Entomology 19(2): 108-110 https://doi.org/10.1111/j.1365-2311.1994.tb00399.x

Gökçe A \& Er M K (2005). Pathogenicity of Paecilomyces spp. to the glasshouse whitefly, Trialeurodes vaporariorum, with some observations on the fungal infection process. Journal of Turkish Agriculture and Forestry 29: 331-339

Isman M B (2006). Plant essential oils for pest and disease management. Crop Protection 19: 603-608 https://doi.org/10.1016/s02612194(00)00079-x

Khashaveh A, Ziaee M \& Safaralizadeh M H (2011). Control of pulse beetle, Callosubruchus maculatus F. (Coleoptera: Bruchidae) in different cereals using spinosad dust in storage conditions. Journal of Plant Protection Research 51(1): 77-81 https://doi.org/10.2478/v10045-011-0014-z

Khetan S K (2001). Microbial pest control. Marcel Dekker Publications, New York

Kılıç E, Güven Ö, Baydar \& Karaca İ (2019). The mortality effects of some entomopathogenic fungi against Helicoverpa armigera, Spodoptera littoralis, Tenebrio molitor and Blattella germanica. Journal of the Faculty of Veterinary Medicine, Kafkas University 25(1): 33-37 https://doi.org/10.9775/kvfd.2018.20278

Komaki M, Kordalı Ş, Usanmaz Bozhüyük A, Altınok H H, Kesdek M, Şimşek D \& Altınok M A (2017). Laboratory assessment for biological control of Tribolium confusum du Val., 1863 (Coleoptera: Tenebrionidae) by Entomopathogenic fungi. Journal of Turkish Entomology 41(1): 95-103 https://doi.org/10.16970/ted.80578

Mahfuz I \& Khalequzzaman M (2007). Contact and fumigant toxicity of essential oils against Callosobruchus maculatus. University Journal Zoology, Rajshahi University 26: 63-66 https://doi.org/10.3329/ujzru.v26i0.701

Marshall R K, Lester M T, Glare T R \& Christeller J T (2003). The fungus, Lecanicillium muscarium, is an entomopathogen of passionvine hopper (Scolypopa australis). New Zealand Journal of Crop and Horticultural Science 31: 1-7 https://doi.org/10.1080/01140671.2003.9514229

Mauchline N A \& Stannard K A (2013). Evaluation of selected entomopathogenic fungi and bio-insecticides against Bactericera cockerelli (Hemiptera). New Zealand Plant Protection 66: 324-332 https://doi.org/10.30843/nzpp.2013.66.5707 
Moina A, Alves S B \& Pereira R M (1998). Efficacy of Beauveria bassiana (Balsamo) Vuillemin isolates for control of stored grain pests. Journal of Applied Entomology 122: 301-305 https://doi.org/10.1111/j.1439-0418.1998.tb01501.x

Muştu M, Demirci F \& Koçak E (2011). Mortality effects of Isaria farinosa (Holm.) and Beauveria bassiana (Bals.) Vuillemin (Sordariomycetes: Hypocreales) on Aelia rostrata Boh. (Hemiptera: Pentatomidae). Journal of Turkish Entomology 35 (4): $559-568$

Muştu M, Demirci F \& Koçak E (2014). Mortality of Isaria farinosa and Beauveria bassiana on sunn pests Eurygaster integriceps and Eurygaster austriaca. Phytoparasitica 42: 93-97 https://doi.org/10.1007/s12600-013-0342-9

Ofuya Z \& Akhidue V (2005). The role of pulses in human nutrition: A review. Journal of Applied Sciences and Environmental Management 9(3): 99-104 https://doi.org/10.4314/jasem.v9i3.17361

Reddy G V P, Zhao Z \& Hubner R A (2014). Laboratory and field efficacy of entomopathogenic fungi for the management of the sweetpotato weevil, Cylas formicarius (Col.: Brentidae). Journal of Invertebrate Pathology 122: 10-15 https://doi.org/10.1016/j.jip.2014.07.009

Remya R (2007). Evaluation of pulse genotypes and efficacy of diatomaceous earth against different life stages of Callosobruchus chinensis (L.). MSc Thesis, Department of Agricultural Entomology, College of Agricultural, University of Agricultural Science, Dharwad, India

Serale T \& Doberski J (1984). An investigation of the entomogenous fungus Beauveria bassiana as a potential biological control agent for Oryzaephilus surinamensis. Journal of Stored Product Research 20: 17-24 https://doi.org/10.1016/0022-474x(84)90031-6

Sevim A, Demir İ, Tanyeli E \& Demirbağ Z (2010). Screening of entomopathogenic fungi against the European spruce bark beetle, Dendroctonus micans (Coleoptera: Scolytidae). Biocontrol Science and Technology 20: 3-11 https://doi.org/10.1080/09583150903305737

Sevim A, Demir I, Sönmez E, Kocaçevik S \& Demirdağ Z (2013). Evaluation of entomopathogenic fungi against the sycamore lace bug, Corythucha ciliata (Say) (Hemiptera: Tingidae). Journal of Turkish Agriculture and Forestry 37: 595-603 https://doi.org/10.3906/tar$1208-55$

Sheeba G, Seshadri S, Raja N, Janarthanan S \& Ignacimuthu S (2001). Efficacy of Beauveria bassiana for control of the rice weevil Sitophilus oryzae (L.) (Coleoptera: Curculionidae). Applied Entomology and Zoology 36(1): 117-120 https://doi.org/10.1303/aez.2001.117

Shifa Vanmathi J, Padma Latha C \& Ranjit Singh A J A (2011). Impact of entomopathogenic fungus, Beauveria bassiana on stored grains pest, Callosobruchus maculatus (F.) (Coleoptera: Bruchidae). Journal of Biopesticides 4(2): 194-197

Singh S R \& Van Emden H F (1979). Insect pest of grain legumes. Annual Review of Entomology 24: 225-278

Simova S \& Draganova S (2003). Virulence of isolates of entomopathogenic fungi to Tetranychus urticae K. (Tetranychidae: Acarina). Plant Science 40: 87-90

Usanmaz Bozhüyük A, Kordali Ş, Kesdek M, Şimşek D, Altınok M A, Altınok H H \& Komaki A (2018). Mortality effects of six different entomopathogenic fungi strains on rice weevil, Sitophilus oryzae (L.) (Coleoptera: Curculionidae). Fresenius Environmental Bulletin 27(6): 4373-4380 https://doi.org/10.16970/ted.80578

Vidal C, Lace L A \& Jacques F (1997). Pathogenicity of Paecilomyces fumosoroseus (Deuteromycotina: Hyphomycetes) against Bemisia argentifolii (Homoptera: Aleyrodidae) with a description of a bioassay method. Journal of Economic Entomology 90(3): 765-772 https://doi.org/10.1093/jee/90.3.765

Yang S, Zhuang H, Li Y \& Kuang R (2009). Insecticidal efficacy of Isaria farinosa in different life stages of Pissodes punctatus (Coleoptera: Curculionidae). Journal of Pest Science 82: 321-325 https://doi.org/10.1007/s10340-009-0256-y

Zimmermann G (2008). The entomopathogenic fungi Isaria farinosa (formerly Paecilomyces farinosus) and the Isaria fumosorosea species complex (formerly Paecilomyces fumosoroseus): Biology, ecology and use in biological control. Biocontrol Science and Technology 18: 865-901 https://doi.org/10.1080/09583150802471812

C 2021 by the authors. Licensee Ankara University, Faculty of Agriculture, Ankara, Turkey.

This article is an open access article distributed under the terms and conditions of the Creative

Commons Attribution (CC BY) license (http://creativecommons.org/licenses/by/4.0/). 